DOI: $10.5277 /$ EPE120312

\title{
MODELLING OF ATMOSPHERIC NITROGEN DEPOSITION EFFECTS TO POLISH TERRESTRIAL ECOSYSTEMS FOR VARIOUS EMISSION SCENARIOS UNTIL THE TARGET YEAR 2020
}

\begin{abstract}
Biogeochemical effects to Polish terrestrial ecosystems resulting from atmospheric nitrogen deposition were forecasted until the target year 2020. To this end recently updated critical loads of nutrient nitrogen were applied and the nitrogen deposition projections for the sequence of decades from 1980 until the target year 2020, based on the Current Legislation (CLE) and Maximum Feasible Reductions (MFR) emission scenarios. The predictions were done by use of the Very Simple Dynamic (VSD) Model developed within the Working Group on Effects of the UN ECE Convention on the Long-Range Transboundary Air Pollution CLRTAP. The calculations were done for three main forest ecosystems and three selected semi-natural ecosystems encompassing the whole territory of Poland with the spatial resolution defined by a grid cell of $1 \times 1 \mathrm{~km}$ size. The study concluded with maps of $\mathrm{CL}_{\text {nut }}(\mathrm{N})$ exceedances and expected nitrogen concentrations in soil as chemical criterion, assigned to different eutrophication risk categories for each deposition scenario. The obtained results show that in spite of the realistic (CLE scenario) and extreme (MFR) nitrogen emission reductions until 2020, more than $99 \%$ and $80 \%$ of total area of terrestrial ecosystems of Poland, respectively, will be exposed to excessive nitrogen deposition. Results of this study as well as studies done on the European scale reveal that the nitrogen emission reductions determined by the Gothenburg Protocol are still insufficient and may lead to negative ecological effects including loss of ecosystems biodiversity. This substantiates a demanding need for the revision of the CLRTAP Gothenburg Protocol.
\end{abstract}

\section{INTRODUCTION}

The review of the Protocol to Abate Acidification, Eutrophication and Groundlevel Ozone (The Gothenburg Protocol) of the UN ECE Convention on the LongRange Transboundary Air Pollution (CLRTAP) showed that biogeochemical effects

\footnotetext{
*Institute of Environmental Protection, National Centre for Emission Management (KOBiZE), Section of Mathematical Modelling, ul. Grunwaldzka 7B/2, Siemianowice Śl., Poland; corresponding author W. Mill, e-mail: mill@silesia.top.pl
} 
of nitrogen deposition to terrestrial ecosystems across Europe will be the main challenges after the year 2010, i.e. the target year of the Gothenburg Protocol [1].

Nitrogen deposition and the resulting habitat eutrophication were identified as one of the most important threats to biodiversity within the following international programs: 2010 Biodiversity Target [2] managed by the Convention on Biological Diversity and the SEBI 2010 [3] developed by the EU Commission and European Environment Agency.

The effects of the eutrophication of habitats are also observed in Polish terrestrial ecosystems. Long-term analysis of ground vegetation change in Białowieża Primeval Forest in the period 1959-1999 showed a decreasing number of conifer associated species and increasing number of species associated with eutrophic deciduous forests [4]. Climate change and habitats eutrophication are considered the reasons of that change.

Since late 1980s, the critical loads concept has been providing a theoretical foundation for the assessment of sulfur and nitrogen deposition effects on natural ecosystems, and critical load of nutrient nitrogen $\left(\mathrm{CL}_{\text {nut }}(\mathrm{N})\right)$ is a quantitative estimate of an exposure to nutrient nitrogen below which significant harmful effects in ecosystems do not occur according to present knowledge [5] . The prediction for 2010 revealed that in spite of Gothenburg Protocol emission reduction fulfilment, 97,4\% of terrestrial ecosystems area in Poland will be exposed to eutrophication leading to degradation of soil chemical structure and biological diversity depletion [6].

Taking this into consideration mathematical modelling, simulation was done to assess the ecological consequences of two scenarios of nitrogen emission predicted for the year 2020 set as the target year for the revision of the Gothenburg Protocol and the Clean Air for Europe (CAFE) program of the European Commission.

\section{MATERIALS AND METHODS}

Ecosystems considered, spatial organization and soil data applied. Terrestrial ecosystems of Poland were the subject of this study. Types and total areas of considered ecosystem habitats are presented in Table 1. To characterize the chosen terrestrial habitats in international categories the EUNIS (European Nature Information System) ecosystem classification was applied [7].

The critical load calculations were based on a grid covering the considered ecosystems, defined by a $1 \mathrm{~km}^{2}$ grid square.

Input data on soil properties were derived from the Soil Geographical Data Base for Europe (EUROSOIL) scale 1:1000000, prepared by the Teledetection Laboratory of the Warsaw University of Technology [8]. This database addresses 26 types of soils by FAO soil classification and provides data on physical and chemical soil properties as well as the land use manner. 
List of selected Polish ecosystems sensitive to nitrogen deposition

\begin{tabular}{|c|l|c|c|c|}
\hline \multirow{2}{*}{$\begin{array}{c}\text { EUNIS } \\
\text { code }\end{array}$} & \multicolumn{2}{|c|}{ Ecosystem type } & \multicolumn{3}{|c|}{ Area $\left[\mathrm{km}^{2}\right]$} \\
\cline { 3 - 5 } & & Protected by Law & Other & Total \\
\hline D & Mire, bog and fen habitats & 917.9 & 141.3 & 1059.2 \\
\hline E & Grassland and tall forb habitats & 274.9 & 238.5 & 513.4 \\
\hline F & Heathland, scrub and tundra habitats & 37.7 & 2.7 & 40.4 \\
\hline G1 & Broadleaved deciduous woodland & 8232.0 & 4835.7 & 13067.7 \\
\hline G3 & Coniferous woodland & 34115.7 & 20628.7 & 54744.4 \\
\hline G4 & Mixed deciduous and coniferous woodland & 12672.0 & 7928.8 & 20600.8 \\
\hline & Total & 56250.2 & 33775.8 & 90026.0 \\
\hline
\end{tabular}

$\mathrm{CL}_{\mathrm{NUT}}(\mathrm{N})$ calculation method. To calculate critical loads of nutrient nitrogen $\mathrm{CL}_{\text {nut }}(\mathrm{N})$, the Simple Mass Balance model (SMB) was applied [5]:

$$
\mathrm{CL}_{\text {nut }}(\mathrm{N})=N_{i}+N_{u}+\frac{Q[\mathrm{~N}]_{a c c}}{1-f_{d e}}
$$

where: $N_{i}$ - long term nitrogen immobilization in soil [eq $\cdot \mathrm{ha}^{-1} \cdot \mathrm{yr}^{-1}$ ],$N_{u}-$ nitrogen uptake (biomass removal) [eq $\left.\mathrm{ha}^{-1} \cdot \mathrm{yr}^{-1}\right], Q$ - precipitation surplus $\left[\mathrm{m}^{3} \cdot \mathrm{ha}^{-1} \cdot \mathrm{yr}^{-1}\right],[N]_{\text {acc }}$ - critical (acceptable) nitrogen concentration in soil water $\left[\mathrm{eq} \cdot \mathrm{m}^{-3}\right], f_{d e}$ - denitrification fraction, soil specific $\left(0 \leq f_{d e}<1\right)$.

The detailed description of the SMB model to calculate $\mathrm{CL}_{\text {nut }}(\mathrm{N})$ values can be found in the Modelling and Mapping Manual [5]. Because of a lack of a simple expression for direct dependence of each of the above parameters form nitrogen deposition, all of them need to be calculated as long term average values. The $N_{i}$ values were adopted as dependent on average soil temperatures [9]. The nitrogen uptake by trees $N_{u}$ was calculated from their yearly average yield rate (data from national statistics for years 1985 and 1990-1998) and average concentration of nitrogen in stems and branches. Uptake was calculated for coniferous and deciduous forests. The precipitation surplus $Q$ was calculated from monthly average climate values for Poland for the time series 1901-2000 estimated by Climatic Research Unit and Tyndall Centre for Climate Change Research in School of Environmental Sciences - University of East Anglia [10]. Denitrification fraction $f_{d e}$ depends on soil type and is based on granulometric composition of soil [5]. These data were derived from the EUROSOIL database. Critical (acceptable) nitrogen concentrations in soil water $[\mathrm{N}]_{a c c}$ were adopted from the Modelling and Mapping Manual [5].

Dynamic modelling. The purpose of dynamic modelling is to assess time delays of recovery in regions where exceedance of critical loads is declining and time delays of 
damage in regions where critical loads continue to be exceeded. For dynamic modelling of the ecosystem response for nitrogen deposition the Very Simple Dynamic model (VSD) was used [11, 12]. The VSD model is designed as the simplest extension of the SMB model for critical loads and used for the Gothenburg Protocol revision process. The soil chemical properties - especially carbon and nitrogen concentrations in soil - were provided for selected monitoring sites from the intensive II-level forest monitoring system funded by the Chief Inspectorate of Environment Protection and operated by the Forest Research Institute.

The nitrogen deposition data for Poland were based on the official emission scenario developed and used by the Centre for Integrated Assessment Modelling (CIAM), [13]. Historical nitrogen deposition scenario for the period 1980-2010 and the two following future scenarios for the years 2010 and 2020 were applied in this study:

- CLE 2020 - (Current Legislation) developed as the base scenario for Baseline Scenarios for the Clean Air for Europe (CAFE) in accordance with European Commission NEC Directive and LCP Directive,

- MFR 2020 - (Maximum Feasible Reduction) scenario where full application of all presently available technical emission control measures is planned for use.

\section{RESULTS AND DISCUSSION}

\subsection{MODELLED $\mathrm{CL}_{\text {nut }}(\mathrm{N})$ VALUES}

The mean $\mathrm{CL}_{\text {nut }}(\mathrm{N})$ value for all considered ecosystems amounts to $377.4 \mathrm{eq} \cdot \mathrm{ha}^{-1} \cdot \mathrm{yr}^{-1}$, while the minimum-maximum values range from 104.8 to $3671.4 \mathrm{eq} \cdot \mathrm{ha}^{-1} \cdot \mathrm{yr}^{-1}$. Average values for each of the habitat types are summarized in Table 2 .

Table 2

Calculated $\mathrm{CL}_{\text {nut }}(\mathrm{N})$ for each ecosystem types

\begin{tabular}{|c|l|c|c|}
\hline \multirow{2}{*}{$\begin{array}{c}\text { EUNIS } \\
\text { code }\end{array}$} & \multicolumn{1}{|c|}{ Ecosystem type } & \multicolumn{2}{c|}{ Average $\mathrm{CL}_{\mathrm{nut}}(\mathrm{N})$} \\
\cline { 3 - 4 } & & {$\left[\mathrm{eq} \cdot \mathrm{ha}^{-1} \cdot \mathrm{yr}^{-1}\right]$} & {$\left[\mathrm{kg} \mathrm{N} \cdot \mathrm{ha}^{-1} \cdot \mathrm{yr}^{-1}\right]$} \\
\hline G1 & Broadleaved deciduous woodland & 515.4 & 7.22 \\
\hline G3 & Coniferous woodland & 304.2 & 4.26 \\
\hline G4 & Mixed deciduous and coniferous woodland & 421.7 & 5.90 \\
\hline D & Mire, bog and fen habitats & 334.5 & 4.68 \\
\hline E & Grassland and tall forb habitats & 694.8 & 9.73 \\
\hline F & Heathland, scrub and tundra habitats & 619.6 & 8.67 \\
\hline
\end{tabular}


Figure 1 presents the spatial distribution of the calculated $\mathrm{CL}_{\text {nut }}(\mathrm{N})$ values for Polish terrestrial ecosystems in a $1 \times 1 \mathrm{~km}$ grid.

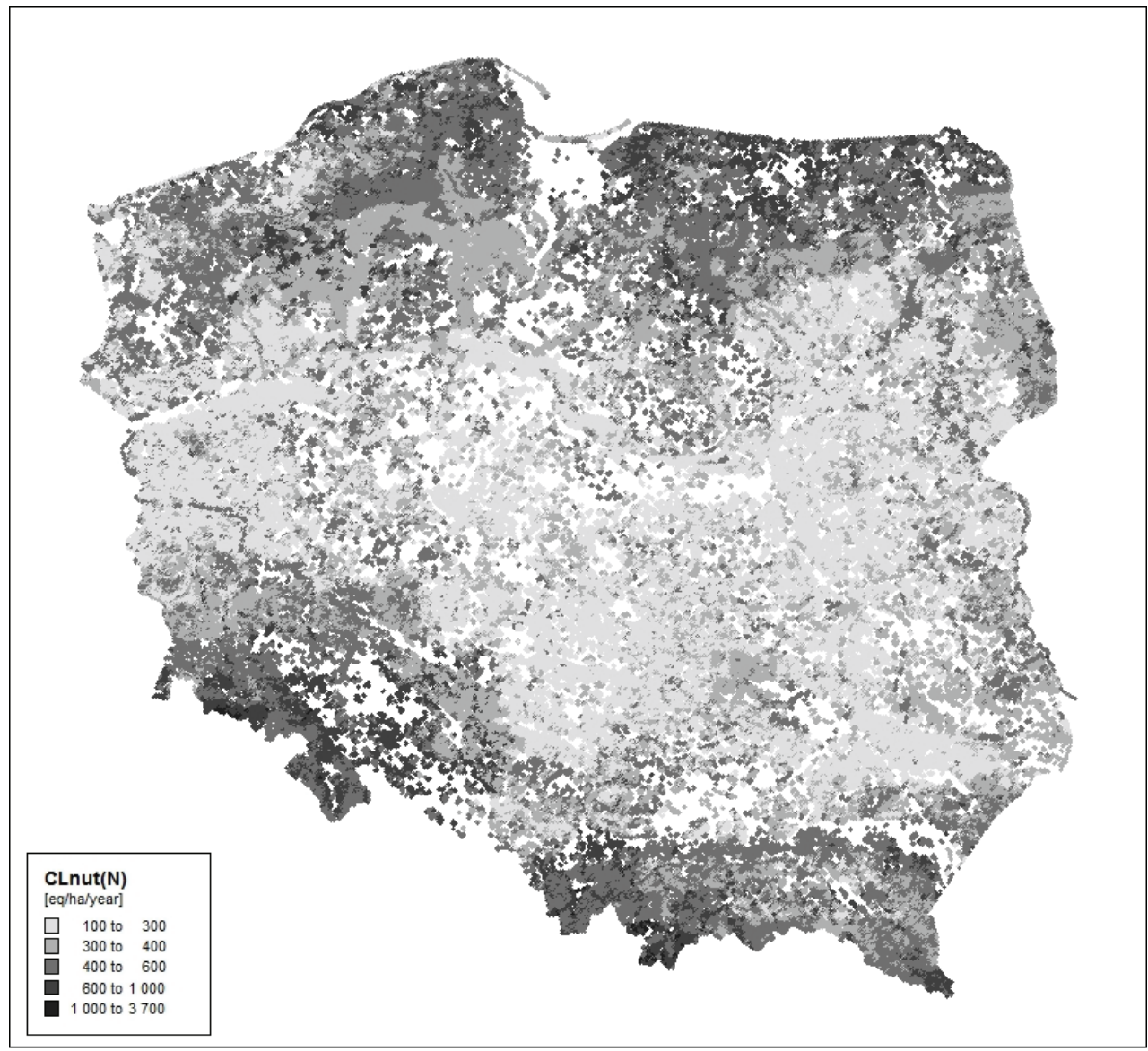

Fig. 1. Spatial distribution of $\mathrm{CL}_{\text {nut }}(\mathrm{N})$ for Polish terrestrial ecosystems in a $1 \times 1 \mathrm{~km}$ grid [eq $\cdot \mathrm{ha}^{-1} \cdot \mathrm{yr}^{-1}$ ]

The lowest critical loads, implying the highest sensitivity to nitrogen deposition, occupy the central part of Poland. The highest critical loads, meaning the highest resistance to nitrogen deposition effects, are located in the northern and southern areas of Poland. Such a dislocation of the $\mathrm{CL}_{\text {nut }}(\mathrm{N})$ values is driven by the spatial distribution of precipitation surplus a parameter of the major influence on $\mathrm{CL}_{\text {nut }}(\mathrm{N})$ values.

The obtained $\mathrm{CL}_{\text {nut }}(\mathrm{N})$ values were submitted to the $\mathrm{CCE}$ where they were aggregated together with other national values into European databases and maps. These maps of a $50 \times 50 \mathrm{~km}$ spatial resolution provide a scientific basis for the ongoing renegotiations of the Gothenburg Protocol. 


\subsection{DYNAMIC MODELLING}

In general there are two basic constraints substantiating the application of dynamic modelling i.e. the critical load exceedance and the violation of the critical chemical limits. Four combinations are possible between the two states defined as risk categories [14]:

Risk category 1: critical load is not exceeded and chemical criterion is not violated - no reduction of emission is needed.

Risk category 2: no critical load exceedance and chemical criterion violated - no further emission reduction needed, only time is required to reach the recovery of ecosystem - a rather rare status.

Risk category 3: critical load exceeded and chemical criterion not violated - emission reduction needed within the time to avoid the ecosystem damage because of chemical criterion violation

Risk category 4: critical load exceeded and chemical criterion violated - immediate risk of ecosystem damage, emission reduction needed to reduce exceedance and bring nitrogen deposition to critical load reversing this way chemical criterion violation.

Thus, the dynamic modelling effort was preceded with an identification of the extent and magnitude of exceedance of nutrient nitrogen critical loads within the considered terrestrial ecosystems and further on areas where the accepted chemical criterion was violated.

\subsubsection{ANALYSIS OF EXCEEDANCES OF $\mathrm{CL}_{\text {nut }}(\mathrm{N})$}

Analysis of ecosystem response to atmospheric nitrogen deposition, defined as critical load exceedance, was done for CLE and MFR deposition scenarios. Exceedances of $\mathrm{CL}_{\text {nut }}(\mathrm{N})$ are calculated as a difference between $N_{\text {dep }}$ and calculated $\mathrm{CL}_{\text {nut }}(\mathrm{N})$. The total exceedances of $\mathrm{CL}_{\text {nut }}(\mathrm{N})$ for all considered ecosystem of Poland are shown in Table 3.

Exceedances of $\mathrm{CL}_{\text {nut }}(\mathrm{N})$ for all selected ecosystems of Poland

\begin{tabular}{|c|c|c|}
\hline \multirow{2}{*}{ Year } & \multicolumn{2}{|c|}{ ExCL $_{\text {nut }}(\mathrm{N})\left[\mathrm{Meq} \cdot \mathrm{ha}^{-1} \cdot \mathrm{yr}^{-1}\right]$} \\
\cline { 2 - 3 } & MFR scenario & CLE scenario \\
\hline 1980 & - & 386313 \\
\hline 1990 & - & 351158 \\
\hline 2000 & - & 187251 \\
\hline 2010 & - & 156398 \\
\hline 2020 & 37015 & 131459 \\
\hline
\end{tabular}


Temporal development of total areas of selected terrestrial ecosystems including legally protected areas, where $\mathrm{CL}_{\text {nut }}(\mathrm{N})$ values are exceeded is shown in Table 4.

Table 4

Area of selected terrestrial ecosystems where $\mathrm{CL}_{\text {nut }}(\mathrm{N})$ values are exceeded

\begin{tabular}{|c|c|c|c|c|c|c|c|c|}
\hline \multirow{3}{*}{ Year } & \multicolumn{4}{|c|}{ Area of $\mathrm{CL}_{\text {nut }}(\mathrm{N})$ exceedance $\left[\mathrm{km}^{2}\right]$} & \multicolumn{4}{|c|}{ Contribution to total area [\%] } \\
\hline & \multicolumn{2}{|c|}{$\begin{array}{c}\text { MFR } \\
\text { deposition scenario }\end{array}$} & \multicolumn{2}{|c|}{$\begin{array}{c}\text { CLE } \\
\text { deposition scenario }\end{array}$} & \multicolumn{2}{|c|}{$\begin{array}{c}\text { MFR } \\
\text { deposition scenario }\end{array}$} & \multicolumn{2}{|c|}{$\begin{array}{c}\text { CLE } \\
\text { deposition scenario }\end{array}$} \\
\hline & $\begin{array}{c}\text { Total } \\
\text { area }\end{array}$ & $\begin{array}{l}\text { Protected } \\
\text { area }\end{array}$ & $\begin{array}{c}\text { Total } \\
\text { area }\end{array}$ & $\begin{array}{l}\text { Protected } \\
\text { area }\end{array}$ & $\begin{array}{l}\text { Total } \\
\text { area }\end{array}$ & $\begin{array}{l}\text { Protected } \\
\text { area }\end{array}$ & $\begin{array}{l}\text { Total } \\
\text { area }\end{array}$ & $\begin{array}{c}\text { Protected } \\
\text { area }\end{array}$ \\
\hline 1980 & - & - & 89924 & 56248.5 & - & - & 99.9 & 100.0 \\
\hline 1990 & - & - & 89924 & 56189.2 & - & - & 99.9 & 99.9 \\
\hline 2000 & - & - & 89811 & 56127.8 & - & - & 99.8 & 99.8 \\
\hline 2010 & - & - & 89777 & 56104.2 & - & - & 99.8 & 99.7 \\
\hline 2020 & 78943 & 48147 & 89722 & 56055.2 & 87.7 & 85.6 & 99.7 & 99.7 \\
\hline
\end{tabular}

3.2.2. ANALYSIS OF VIOLATION OF [N] CHEMICAL CRITERION

Total areas of Polish terrestrial ecosystems including protected areas, where $[N]$ chemical criterion is violated are shown in Table 5.

Table 5

Areas of ecosystems in Poland where $[\mathrm{N}]$ criterion is violated

\begin{tabular}{|c|c|c|c|c|c|c|c|c|}
\hline \multirow{4}{*}{\begin{tabular}{c} 
Year \\
\cline { 2 - 9 }
\end{tabular}} & \multicolumn{2}{|c|}{ Area of $[\mathrm{N}]$ criterion violation $\left[\mathrm{km}^{2}\right]$} & \multicolumn{3}{c|}{ Contribution to total area [\%] } \\
\cline { 2 - 9 } & $\begin{array}{c}\text { MFR } \\
\text { deposition scenario }\end{array}$ & \multicolumn{2}{c|}{$\begin{array}{c}\text { CLE } \\
\text { deposition scenario }\end{array}$} & \multicolumn{2}{c|}{$\begin{array}{c}\text { MFR } \\
\text { deposition scenario }\end{array}$} & \multicolumn{2}{c|}{$\begin{array}{c}\text { CLE } \\
\text { deposition scenario }\end{array}$} \\
\hline \multirow{2}{*}{1980} & - & $-\begin{array}{c}\text { Protected } \\
\text { area }\end{array}$ & $\begin{array}{c}\text { Total } \\
\text { area }\end{array}$ & $\begin{array}{c}\text { Protected } \\
\text { area }\end{array}$ & $\begin{array}{c}\text { Total } \\
\text { area }\end{array}$ & $\begin{array}{c}\text { Protected } \\
\text { area }\end{array}$ & $\begin{array}{c}\text { Total } \\
\text { area }\end{array}$ & $\begin{array}{c}\text { Protected } \\
\text { area }\end{array}$ \\
\hline 1990 & - & - & 89434.8 & 56050.2 & - & - & 99.4 & 99.6 \\
\hline 2000 & - & - & 89576.4 & 56085.6 & - & - & 99.6 & 99.7 \\
\hline 2010 & - & - & 88719.8 & 55318.5 & - & - & 98.6 & 98.3 \\
\hline 2020 & 74706.6 & 44993.3 & 88263.7 & 54908.0 & 83.0 & 80.0 & 98.1 & 97.6 \\
\hline
\end{tabular}

\subsubsection{ASSESSMENT OF EUTROPHICATION RISK CATEGORIES}

The final assessment of the eutrophication was done by analyzing the development of areas assigned to individual risk categories defined in the introduction to Section 3.2 . 
The ecosystems areas were allocated to each category of eutrophication risk from 1 (no risk - ecosystem is safe) to 4 (highest risk - ecosystem is damaged). Results for considered deposition scenarios are shown in Table 6.

Table 6

Area of ecosystems for each risk category for different deposition scenarios up to 2020

\begin{tabular}{|c|c|c|c|c|c|c|c|}
\hline \multirow{2}{*}{$\begin{array}{c}\text { EUNIS } \\
\text { code }\end{array}$} & \multicolumn{5}{|c|}{$\begin{array}{c}\text { Area of ecosystems } \\
\text { for each risk category [\%] }\end{array}$} \\
\cline { 2 - 8 } & Exceedance of $\mathrm{CL}_{\text {nut }}(\mathrm{N})$ & \multicolumn{2}{|c|}{$[\mathrm{N}]$ criterion violated } & 1 & 2 & 3 & 4 \\
\hline \multicolumn{5}{|c|}{ CLE emission scenario } \\
\hline F & 33.6 & 28.3 & 66.4 & 0.0 & 5.3 & 28.3 \\
\hline E & 72.4 & 0.0 & 27.1 & 0.5 & 23.0 & 49.5 \\
\hline D & 95.6 & 19.4 & 4.4 & 0.0 & 76.2 & 19.4 \\
\hline G1 & 99.9 & 97.4 & 0.1 & 0.0 & 2.5 & 97.4 \\
\hline G3 & 100.0 & 99.8 & 0.0 & 0.0 & 0.2 & 99.8 \\
\hline G4 & 100.0 & 99.4 & 0.0 & 0.0 & 0.6 & 99.4 \\
\hline All & 99.7 & 97.8 & 0.3 & 0.0 & 1.7 & 98.1 \\
\hline & & MFR emission scenario & & & \\
\hline F & 12.7 & 10.5 & 87.3 & 0.0 & 2.2 & 10.5 \\
\hline E & 46.1 & 2.8 & 53.9 & 0.0 & 43.3 & 2.8 \\
\hline D & 51.4 & 0.5 & 48.6 & 0.0 & 50.9 & 0.5 \\
\hline G1 & 55.0 & 53.9 & 40.2 & 4.9 & 6.0 & 49.0 \\
\hline G3 & 98.9 & 97.1 & 0.9 & 0.2 & 1.9 & 97.0 \\
\hline G4 & 80.0 & 70.4 & 17.9 & 2.1 & 11.7 & 68.3 \\
\hline All & 87.3 & 83.0 & 11.4 & 1.3 & 5.5 & 81.7 \\
\hline
\end{tabular}

Until 2020 , only $0.3 \%$ of the whole ecosystem area will be assigned to the 1 st eutrophication risk category, under the CLE emission scenario. Over $98 \%$ of Polish ecosystems are qualified to category 4 , where both $\mathrm{CL}_{\text {nut }}(\mathrm{N})$ and $[\mathrm{N}]$ criteria are exceeded. For this category, the ecosystem recovery may not occur until the year 2020.

For the same time horizon but under the MFR emission scenario, the total ecosystems area assigned to the 1 st risk spreads over $11.4 \%$. But in spite of such drastic reduction of nitrogen emission, still almost $82 \%$ of Polish ecosystem areas remain under the 4th category.

The above reported high contribution of the 4th risk category is principally related to forest ecosystems. In the case of grassland and tall forbs habitats (E) as well as heathland, scrub and tundra habitats (F) there is a remarkable contribution of the 3rd risk category for both considered emission scenarios for the year 2020 . 


\subsection{ASSESSMENT OF THE FORMER AND FUTURE DEVELOPMENT OF EUTROPHICATION RISK TO POLISH TERRESTRIAL ECOSYSTEMS}

In 1980 almost the whole area of Poland was both, at acidification and eutrophication risk caused by sulphur and nitrogen deposition, although the main negative and visible effect was addressed to acidification, resulting in tree injuries and even in forest dies in some areas of Central Europe. The recent review of the Gothenburg Protocol made known that despite the acidification abatement still remains a problem, further nitrogen emission reduction to combat eutrophication should politically become of prime importance in Europe. This conclusion refers especially to Poland, what is documented by the outcome from this study summarized below.

Under the CLE nitrogen emission scenario, practically no decrease in ecosystem areas where $\mathrm{CL}_{\text {nut }}(\mathrm{N})$ and $[\mathrm{N}]$ criterion is exceeded for the whole 1980-2020 time span is shown (Table 6). Only for non-forest shrub habitats (EUNIS code F) located at southern border (Sudety, Tatry and Bieszczady Mts.) and northern part of Poland recovery is expected and ca. 66\% of its total area will be protected in 2020 (Table 9). Safe areas covered by grass and tall forbs habitats (E) as well as mire, bog and fen habitats (D) are also predicted to increase by ca. $27 \%$ and $4 \%$ respectively.

Analyzing the effects of the MFR scenario for the year 2020, the safety zone will extend to about $12 \%$ for all ecosystems and ca. $15 \%$ for protected areas (Table 6). This is mainly due to the increment of protected areas of deciduous forest in the northern and southern part of the country (Table 9).

Generally, forest habitats (EUNIS code G), and especially coniferous forest stands (G3), will still remain at risk of eutrophication under the both MFR and CLE scenarios until 2020, except mountain areas and north-eastern regions of Poland. This is in accordance with the CCE findings that for most European countries, especially in Western and Central Europe, reductions of nitrogen emission will be still insufficient even under the 2020 emission reduction projections [15].

\section{CONCLUSIONS}

- The mean value of CLnut(N) calculated for Polish terrestrial ecosystems amounts to 377 [eq ha $-1 \cdot \mathrm{yr}-1$ ], with minimum-maximum 105-3671 [eq·ha-1/yr-1] which corresponds with the average values for Central Europe reported by the CCE.

- Analyzing the exceedances of $\mathrm{CL}_{\text {nut }}(\mathrm{N})$ and projected nitrogen chemical criterion on the national scale in dependence on different deposition scenarios until 2020, the following conclusions may be drawn:

- Under the nitrogen deposition from 1980 the of $\mathrm{CL}_{\text {nut }}(\mathrm{N})$ exceedances and violation of nitrogen concentration criterion in soil solution occurred on the whole territory of Poland. 
- Up to 2020, a significant decrease in total sum of exceedances of $\mathrm{CL}_{\text {nut }}(\mathrm{N})$ is projected amounting to $90 \%$ and $66 \%$ for MFR and CLE emission scenarios, respectively.

- In spite of the above, the total area of exceedances will practically not change under the CLE scenario (decrease by $0.1 \%$ ) while under the MFR scenario, the area with no exceedances will increase only by about $12 \%$. Such a low improvement is mainly addressed to forest ecosystems occupying about $30 \%$ of the all territory.

- Until 2020, the total area of $[\mathrm{N}]$ criterion violation will not change significantly under the CLE scenario (decrease by 1\%) but under the MFR scenario the area with no exceedances will increase by about $20 \%$.

- Under the CLE emission scenario, the 4th risk category dominates for all considered ecosystems contributing by $98 \%$ of their total area. This is mainly due to forest ecosystems. The worse risk category reduces to ca. $82 \%$ under the MFR emission scenario and the contribution of area assigned to the 3rd risk category increases to $5.5 \%$.

- Considering the legally protected areas and individual ecosystems in terms of the above exceedances and nitrogen chemical criterion violation for the same target year, the following is concluded:

- The difference between areas of ecosystems legally protected, where exceedances will exist in 2020, and the related total ecosystem areas is practically not the case of the both considered emission scenarios. This is because the protected areas are largely covered by forests.

- Referring to individual non-forest ecosystems, a high reduction of area at eutrophication risk in the target year 2020 is observed. It applies to such ecosystems like mires, bogs, fens, grass, tall forbs and shrubs (EUNIS codes D, E and F, respectively) covering about $2 \%$ of the total ecosystems area only.

- It is advantageous that the geographical location of the above mentioned ecosystems coincides with the lowest nitrogen deposition zones.

- Results of this study as well as studies done on the European scale reveal that the reductions of nitrogen emission determined by the Gothenburg Protocol are still insufficient and may lead to negative ecological effects including loss of their biodiversity. This substantiates a demanding need for the Gothenburg Protocol revision.

- Based on the LRTAP Convention experience, this kind of study offers a sound scientific basis for development of environmental protection policy on a national level, aimed on the abatement of air pollution effects to natural ecosystems.

\section{ACKNOWLEDGEMENTS}

This work was supported by the Ministry of Science and Higher Education, as well as the Institute of Environmental Protection, grant No. 10OR-BE-1211. 


\section{REFERENCES}

[1] Review of the 1999 Gothenburg Protocol, Review Report of the Working Group on Effects, ECE/EB.AIR/WG.1/2007/14, 2007.

[2] Integration of outcome-oriented targets into the programmes of work of the Convention, taking into account the 2010 biodiversity target, the Global Strategy for Plant Conservation, and relevant targets set by the World Summit on Sustainable Development, Conference of The Parties to the Convention on Biological Diversity, UNEP/CBD/COP/7/20/Add.3, 2003.

[3] Halting the loss of biodiversity by 2010: proposal for a first set of indicators to monitor progress in Europe, EEA Technical Report No. 11, 2007.

[4] PALUCH R., Zmiany zbiorowisk roślinnych i typów siedlisk $w$ drzewostanach naturalnych Białowieskiego Parku Narodowego, Sylwan, 2001, 10, 73-82.

[5] UBA, Manual on Methodologies and Criteria for Modelling and Mapping Critical Loads and Levels and Air Pollution Effects, Risks and Trends, Umweltbundesamt, Berlin, Germany, 2004.

[6] Mill W., Schlama A., KaCPRZYK W., Raport w sprawie aktualizacji map ładunków krytycznych zakwaszenia i eutrofizacji dla ekosystemów leśnych Polski, [in:] Realizacja zadań wynikajacych z ratyfikowanych badź podpisanych przez Rzeczpospolita Polskq wielostronnych umów międzynarodowych oraz członkostwa $w$ agendach i instytucjach powołanych przez Organizację Narodów Zjednoczonych $w$ zakresie ochrony środowiska, Report for year 2005, IOŚ, Warsaw, 2005.

[7] Davies C.E., Moss D., HiLl M.O., EUNIS Habitat Classification Revised 2004, European Environment Agency, European Topic Centre On Nature Protection And Biodiversity, October 2004, 2004.

[8] Soil Geographical Data Base for Europe - Poland (EUROSOIL), S. Białousz (Ed.), The Teledetection Laboratory, Warsaw University of Technology, 2008.

[9] Modelling and Mapping of Critical Thresholds in Europe, M. Posch, P.A.M. Smet, J.-P. Hettelingh, R.J. Downing (Eds.), CCE Status Report 2001, Coordination Centre for Effects, Netherlands Environmental Agency, 2008.

[10] New M., Lister D., Hulme M., Makin I., A high-resolution data set of surface climate over global land areas, Climate Research, 2002, 21, 1-25.

[11] Posch M., ReINDS GJ., VSD - User Manual of the Very Simple Dynamic soil acidification model, Coordination Centre for Effects, RIVM, Bilthoven, The Netherlands, 2005.

[12] Posch M., ReINDS G.J., A very simple dynamic soil acidification model for scenario analyses and target load calculations, Environmental Modelling and Software, 2009, 24 (3), 329-340.

[13] Amann M., Bertok I., Cabala R., Cofala J., Heyes C., Gyarfas F., Klimont Z., Schöpp W., WAGNER F., A final set of scenarios for the Clean Air For Europe (CAFE) programme, Final Report, CAFE Scenario Analysis, Report 6, International Institute for Applied Systems Analysis (IIASA), 2005.

[14] Critical loads of nitrogen and dynamic modelling, CCE Progress Report 2007, J. Slootweg, M. Posch, J.-P. Hettelingh (Eds.), Coordination Centre for Effects, Netherlands Environmental Agency, 2007.

[15] Critical load, dynamic modelling and impact assessment in Europe, CCE Status Report 2008, J.-P. Hettelingh, M. Posch, J. Slootweg (Eds.), Coordination Centre for Effects, Netherlands Environmental Agency, 2008. 